\title{
ラット骨格筋の発育発達に関する基碌的研究 一一筋内增殖細胞と総筋線維数の変化を中心として——
}

\author{
内山秀一王木哲朗 中野昭一

\begin{abstract}
CHANGES IN THE NUMBERS OF PROLIFERATING CELLS AND MUSCLE FIBERS IN GROWING RAT SKELETAL MUSCLE
\end{abstract}

\author{
Shuichi Uchiyama, Tetsuro Tamaki and Shoichi Nakano
}

\begin{abstract}
Changes in the numbers of muscle fibers and proliferating cells detected by immunohistochemistry were studied in correlation with various growth parameters including changes in body weight, lower hindlimb length, muscle length, muscle weight and age in Wistar-strain rats at various developmental stages. The total fiber number in plantaris (PLA) muscles increased gradually between 2 weeks and 10 weeks of age (about $300 \mathrm{~g}$ body weight), and then remained constant between 10,000 and 11,000 these after. In contrast, proliferating cells labeled by bromodeoxyuridine decreased gradually during the same period, and were hardly evident after 10 weeks. In the growth curves for the body weight, lower hindlimb length, muscle weight, and the length of the extensor digitorum longus (EDL) muscle, turning points were observed at 10 weeks ( $300 \mathrm{~g}$ body weight), respectively, suggesting that the turning point between growth in length and growth in width occurred at this point. Furthermore, the growth curves for the body weight and PLA muscle weight were correlated between 2 and 20 weeks, including the turning point. Therefore it is suggested that the development of muscle weight from 2 to 10 weeks depends mainly on the increment of fiber number (hy. perplasia), whereas development after 10 weeks depends on the increment of individual fiber diameter (hypertrophy), in relation to the tendency for an increase in fiber number and a decrease in proliferating cells. These results indicate that maturation of skeletal muscle in male Wistar rats occurs at 10 weeks of age and a body weight of $300 \mathrm{~g}$. Accordingly, these facts should be considered when investigating muscle hypertrophy or hyperplasia.
\end{abstract}

(Jpn. J. Phys. Fitness Sports Med. 1993, $42: 130 \sim 137$ )

key words : skeletal muscle, growth, proliferating cell, hyperplasia, hypertrophy.

I. 粕

言

骨格筋が，運動をはじめとするいわゆる過負荷 により肥大する事実は，これまでヒト及び様々な モデル動物を用い多くの研究者によって確認され ている ${ }^{2,18,22,25)}$.この筋肥大に関しては, 個々の 笳線維がその横断面積を増すことによりもたらさ れ, 筇線維は肥大はするが増殖（増加）はしない とされてきた。これに対し，近年，筋肥大に伴い 筋線維の增加も起こるとする報告 $2,7,8,11)$ るなされ るようになり，現在論争の的となっている.
一方, 筋肥大は, 発育・発達過程に扣いて子起 こっており，成長にともない筋線維は肥大し，筋 線維数も增加することが報告されている5,13).

さらに, 分化を完了した筋線維の肥大, 増殖に は, 筋衛星細胞が関与しているとする報告3,11,12, 16,17)るなされており, 同様に, Allbrook ら ${ }^{11}$ は ${ }^{3} \mathrm{H}-$ チミジンを用いたラジオオートグラフィーによる 検索で, 生後発育にともない活性化した筋衛星細 胞が減少することを示していることから, 発育に ともなら筋線維の肥大, 增殖にも筋衛星細胞が関 与している可能性が示唆される10).このことは, 
筋の肥大あるいは増殖を考える上で常に考虑しな ければならない事項である.すなわち，後天的な 刺激あるいは過負荷による筋肥大, 筋線維の增殖 を検討する場合，発育による影響がどの時期まで 継続するのかを明らかにし，しかも発育・発達に 伴う因子を排除した上で検討する必要があろう.

しかし, 生後発育にともなら筋線維の増殖と活性 化した筋衛星細胞（増殖期細胞）との関係につい て検討した研究はほとんどみられない。

そこで本研究では，ラットの生後発育にともな 万筋線維数の変化及び筋肉内の活性化した筋衛星 細胞 (増殖期細胞) の動向を, 週齢, 体重の推移, 下腿長, 筋長, 及び筋の湿重量の変化等との関連 から免疫組織化学的に検討した.

\section{II. 実 験 方 法}

\section{A. 実験功物及び実験手順}

実験動物は生後 $2 \sim 10$ までの各週齢および15・ 20週龄のウィスター系雄性ラット各 5 匹, 計55匹 を用いた。飼育用ヶージは $30 \times 35 \times 18 \mathrm{~cm}$ で，䬣 (日本クレア；CE-2) 及び水は自由摂取とした. 尚, 飼育室は 12 時間周期で昼夜逆転し, 飼育期間 中の平均室温及び湿度は $24.1 \pm 2.1^{\circ} \mathrm{C}, 39.8 \pm 5.1 \%$ であった.

各週齢のラットに対して体重を測定後, チミシ ンのアナログであり生体内の増殖期 (DNA 合成 期）にある細胞核に特異的に取り込まれる $\mathrm{BrdU}$ (5-bromo-2-deoxyuridine, ベーリンガー・マン ハイム社) $100 \mathrm{mg} / \mathrm{kg}$ body weight ( $\mathrm{pH}$ 調整剤と して $11.6 \mathrm{mg} / 100 \mathrm{mg} \mathrm{BrdU}$ の水酸化ナトリウム を含む $2 \mathrm{~m} l$ の生理食塩水に溶解)を, 腹腔内投与 し筋肉内増殖期細胞を標識した ${ }^{6,8,21)}$. BrdU 投与 30分後ネンブタール (Sodium-pentobarbital : 40 $\mathrm{mg} / \mathrm{kg}$ body weight i. p.) 麻酔下にて屠殺し, 骨 の発育の指標として䐂関節 90 度・足関節 90 度の状 態で大腿骨遠位骨端上部から踵骨底部までを下腿 長として，また同様の状態で，筋の発育の指標と して脛骨に沿って付着し，今回測定した下腿長の 変化に最も影響を受けると考えられる M. Extensor Digitorum Longus (EDL) を露出させ, EDL 長として近位筋腱移行部から遠位筋腱移行部の長
さをキャリパーにて計測した，さらに，両下腿よ り M. Plantaris を摘出し, 湿重量を測定後, 自 然長にてドライアイスーアセトン内で泠却したイ ソペンタン $\left(-70^{\circ} \mathrm{C}\right)$ 中で瞬間凍結し，一方は組織 化学的検索に, 他方は筋線維数の算出に用いた.

\section{B. 分析方法}

1. 組織化学的検索

凍結した試料をクリオスタット内 $\left(-20^{\circ} \mathrm{C}\right)$ で, 2 週龄では 2 分割, $3 \cdot 4$ 週齢では 3 分割, 5 10 週齢では 4 分割, $15 ・ 20$ 週秢では 6 分割し，各 部位ごとに厚さ $10 \mu \mathrm{m}$ の連続切片を作成しほぼ 筋全体の情報が得られるようにした，得られた切 片に対して H. E. 染色及び抗 BrdU を用いた酵素 抗体法 (間接法)による免疫組織化学的染色を施 した.

BrdU 及び抗 BrdU 抗体を用いた酵素抗体法 (間接法)による免疫組織化学的染色は以下の方法 により行った ${ }^{6,9,21)}$.

（1）切片作成後 $70 \%$ エタノールにて15分固定し た。

(2) $0.3 \% \mathrm{H}_{2} \mathrm{O}_{2}$ を加えた $100 \%$ メタノールに 30 分浸漬し，内因性ペルオキシダーゼを阻止した.

（3） $0.01 \mathrm{M}$ リン酸緩衛生理食塩水 (Phosphate Buffered Saline ; PBS pH. 7.4)で洗浄した後， 2 規定塩酸で室温にて60分間処理しDNA 変性を行 った。

(4) 0.01 M PBS で洗浄後, 正常ヒツ ジ血清 (Normal Sheep Serum; NSS)にて30分間処理し， 非特異的抗原抗体反応を阻止した.

(5) 0.01 M PBS で洗浄後, 抗 BrdU 抗体(Becton Dickinson 社製）を滴下し, Moist Chamber (室温) 内で60分間反応させた.

(6) $0.01 \mathrm{M}$ PBS で洗浄後, 標識 2 次抗体 (Horse radish peroxidase ; HRP : 標識抗マウ ス免疫グ ロブリン抗体)を滴下し，Moist Chamber(室温) 内で60分間反応させた.

(7) $0.01 \mathrm{M}$ PBS で洗浄後, $0.02 \% \mathrm{DAB}$ (3-3diaminobenzidine) を含む $0.05 \mathrm{M} ト$ ト・リン 酸緩衝液に $0.005 \%$ の過酸化水素水を加えた溶液 で発色し, 水洗後, エタノール系列にて脱水, キ シレンにて透撤, 封入した. 
さらに, 光学顕微鏡下にて各部位より得られた 連続切片 6 枚, 計 12〜36枚の切片に扣ける総 $\mathrm{BrdU}$ 陽性細胞数をカウントし， 1 切片あたりの 平均增殖期細胞数を算出した.

\section{2. 筇線維数の算出}

筋線維数の算出は, 独自に改良した硝酸法 ${ }^{18)}$ に より行った。すなわち，凍結した試料を蒸留水で 溶解し, $15 \%$ 硝酸で $1.5 \sim 3$ 時間処理, 水洗後 $4{ }^{\circ} \mathrm{C}$ で 1 時間蒸留水に浸漬した後， $4{ }^{\circ} \mathrm{C} 0.01 \mathrm{M}$ PBS に移した。ささらに，数百本の筋束に分割した試料 をシリコンシャーレー上に移し, 実態顕微鏡下で 全筋線維を単離しカウントした.

また，統計処理には最小二乗法による回帰分析 及びピアソンの相関係数を用い，各指標における 発育発達の変曲点を求め, その傾向を回帰直線で 示した.

\section{III. 結果}

Fig. 1 に 3 週齢及び 8 週㱓の $\mathrm{BrdU}$ 陽性細胞を 示した. 細胞間質に細胞核に取り込まれた果粒状 の反応産物が認められる。

Fig. 2 飞, 発育に伴亏筋肉内増殖期 (BrdU 陽 性）細胞数と総筋線維数の推移を示した．各週齢 に打ける切片あたりの增殖期細胞数は，2１0週 齢にかけて直線的に減少し $(\mathrm{Y}=-30.4 \mathrm{X}+293.1$, $\mathrm{r}=-0.97) ， \quad 10$ 週齢以降は㱙之んど観察されなか った. すなわち， 2 週路では平均 $224.99 \pm 15.9$ 個 観察された増殖期細胞は, 5 週龄では平均 $110.08 \pm$ 13.5 個と約半数となり，10 週齢に至っては平均 $6.37 \pm 3.76$ 個となり,さらに 20 週龄では平均 $0.85 \pm$ 0.30 とほとんど認められなかった。 これに対し， 筋線維数は, 増殖期細胞数とは逆に10週齢まで漸 次增加する傾向を示した $(\mathrm{Y}=330.0 \mathrm{X}+7940.5, \mathrm{r}=$ 0.97)。すなわち， 3 週齢時には平均 $8,739 \pm 129.8$ 本であったものが，10週齢では平均 $11,087.6 \pm$ 612.3本となり，そ机以降は約11,000本前後で一定

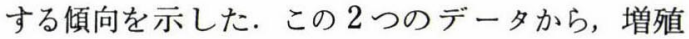
期細胞数及び総筋線維数の週龄に伴ら推移では, 10週龄付近が変曲点となることが示された．

次に, 週齢に伴う体重の推移を Fig. 3 亿示し た. 体重は週跉に伴い漸次増加する傾向を示した。
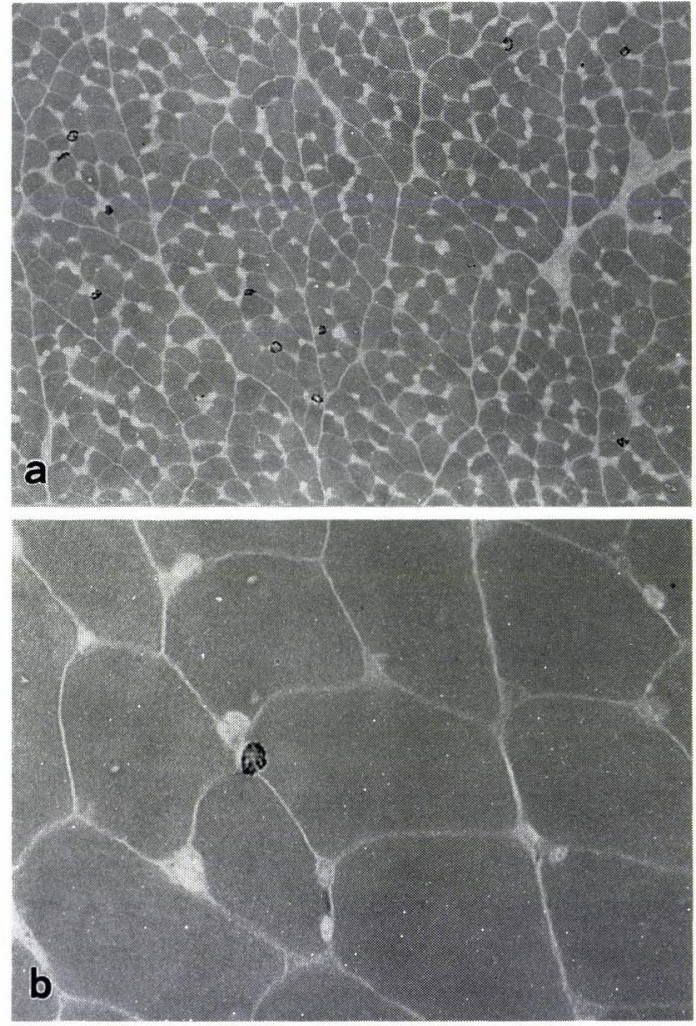

Fig. 1. The proliftrating cells (anti-BrdU positive reactions) were distributed between fibers (a : 3 weeks $x 270)$, and observed nearby muscle fiber. (b: 8 weeks $\times 770$ ).

しかし, 体重の推移にも変曲点が認められ生後 2 週㱓, 平均 $27.4 \pm 2.24 \mathrm{~g}$ から 10 週齢, 平均 $292 \pm$ $14.7 \mathrm{~g}$ にかけては直線的に増加し $(\mathrm{Y}=34.2 \mathrm{X}$ 一 $55.8, \mathrm{r}=0.98)$, それ以降はゆるやかに増加する傾 向を示した $(\mathrm{Y}=10.2 \mathrm{X}+189.0, \mathrm{r}=0.99)$. すなわ ち, 体重の推移では10週齢, 体重 $300 \mathrm{~g}$ 付近を境 に二本の直線で示されることが明かとなった．

Fig. 4 は週秢に伴う M. Plantaris の湿重量の 推移を示したものである. M. Plantarisの湿重量 の推移も，週㱓にともない体重の推移と同様に， 10 週齢, 平均 $288.8 \pm 3.9 \mathrm{mg}$ を境に二本の直線で 示されることが明かとなった。

Fig. 5 には，週蹫に伴う下腿長及び EDL 長の 推移を示した。 下腿長及び EDL 長の推移も共に 10 週路, 体重 $300 \mathrm{~g}$ 付近まで漸次増加し，それ以 降もわずかに増加する傾向を示した，すなわち， 


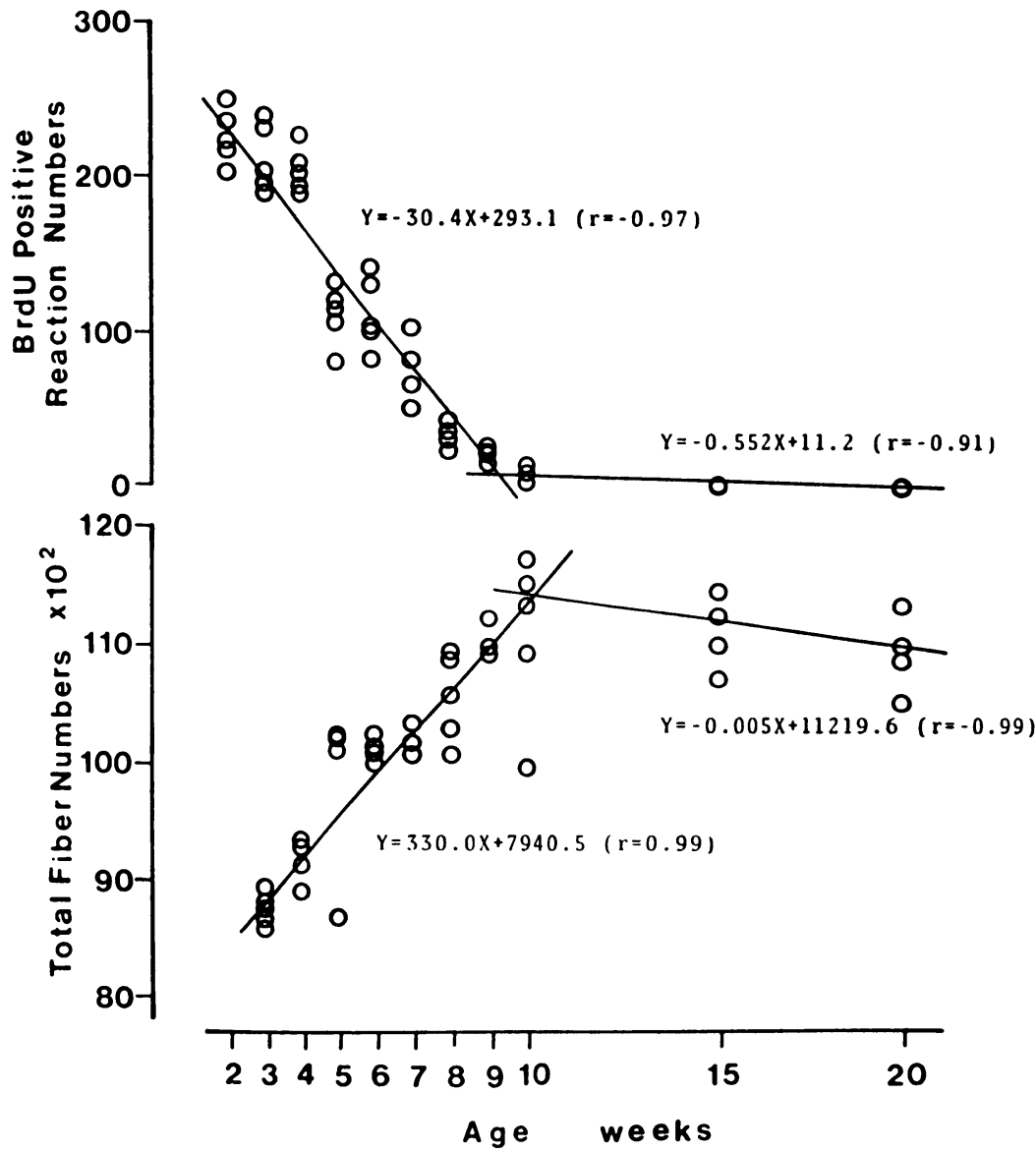

Fig. 2. Changes in number of anti-BrdU positive reactions and muscle fibers of plantaris muscles (PLA). Both parameters gradually decreased (Anti-BrdU positive reactions) or increased (muscle fiber numbers) from 2 to 10 weeks of age, and then both parameters shows constant values after 10 weeks.

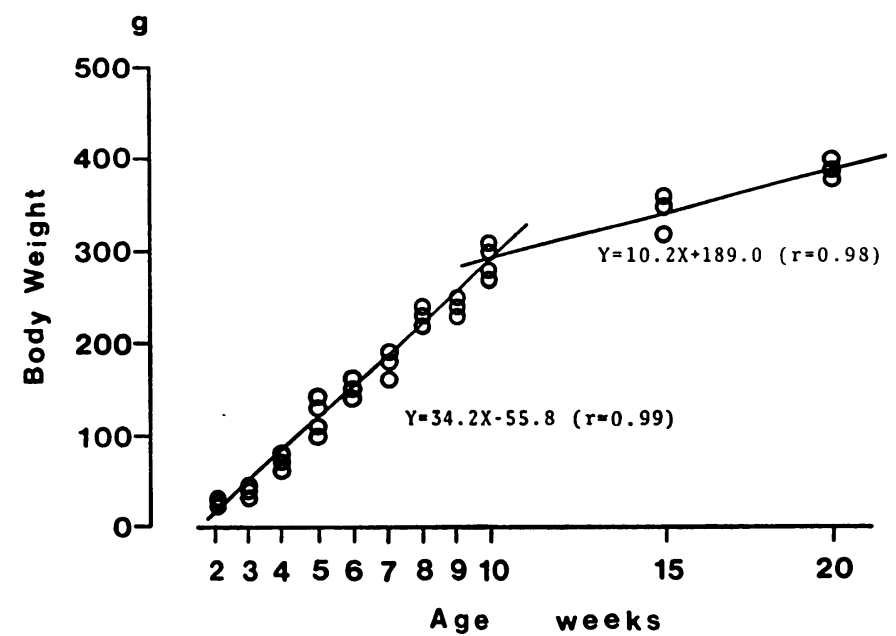

Fig. 3. Changes in body weight. In the growth curve of body weight, the turning point is ovserved at 10 weeks ( $300 \mathrm{~g}$ body weight). 


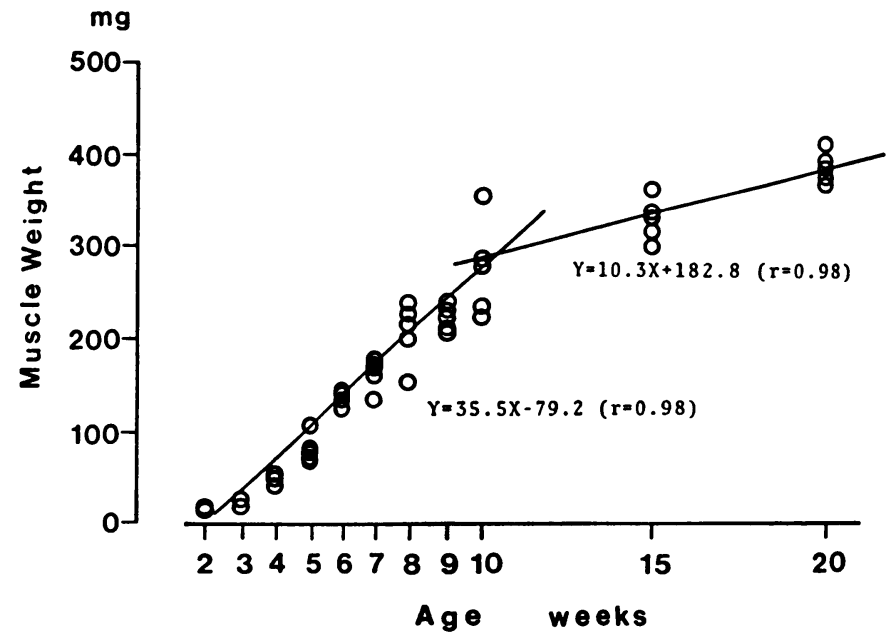

Fig. 4. The growth curve of plantaris muscles (PLA). The muscle weight gradually increased following to the age, however the turning point is also observed at 10 weeks (300 $\mathrm{g}$ body weight).

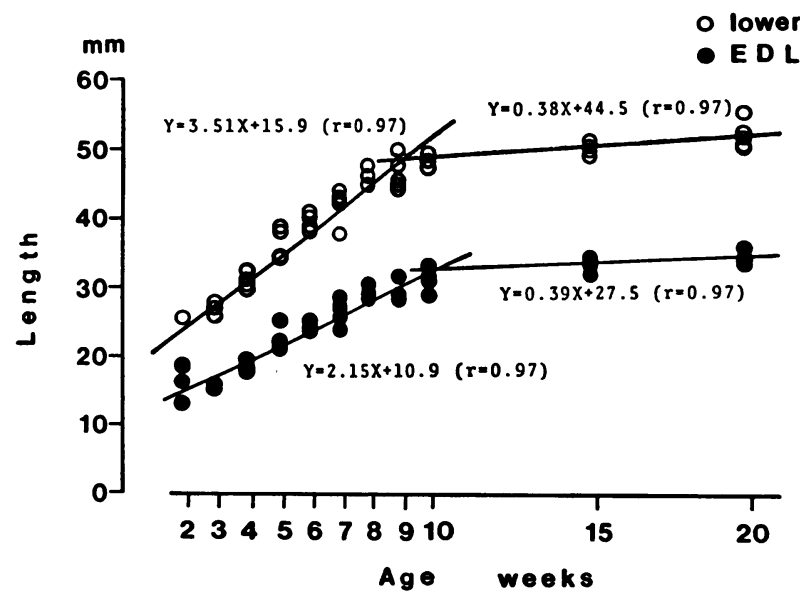

Fig. 5. Changes in the length of lower hindlimbs and extensor digitorum longus muscles (EDL). The turning points were observed in both parameters at 10 weeks $(300 \mathrm{~g}$ body weight), and few increments are observed after 10 weeks of age.

下腿長及び EDL 長の推移においても10週龄, 体 重 $300 \mathrm{~g}$ 付近に変曲点があることが示された. ま た，10週齢までの下腿長及び EDL 長の推移を比 較すると, $\mathrm{EDL}$ 長 $(\mathrm{Y}=2.15 \mathrm{X}+10.9, \mathrm{r}=0.97)$ に 対し下腿長 $(Y=3.51 X+15.9, r=0.97) て ゙$ 増加率が 高い傾向を示した。しかし，10週踰以降は下腿長 $(\mathrm{Y}=0.38 \mathrm{X}+44.5, \mathrm{r}=0.97)$ 及び $\mathrm{EDL}$ 長 $(\mathrm{Y}=0.39$ $\mathrm{X}+27.5, \mathrm{r}=0.97)$ の增加率はほぼ等しくなる傾向 が示された。
IV. 考察

本研究ではウィスター系雄性ラットの発育・発 達に伴う体重, 筋の湿重量, 下腿長, EDL 長, 総 筋線維数の変化及びそれらに伴う筋肉内増殖期細 胞の動向を免疫組織化学的に検討した.

総筋線維数は, 発育に伴って漸次増加し10週齢， 体重 $300 \mathrm{~g}$ 付近を変曲点として 11,000 本前後でほ ぼ一定する傾向を示したのに対し，増殖期細胞数 
は週齢を経るにしたがって漸次減少し，10週秢・ 体重約 $300 \mathrm{~g}$ 付近を境にそれ以降ほとんど認めら

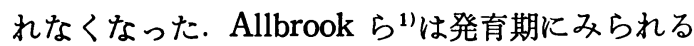
增殖期細胞は主に活性化した筋衛星細胞であり, 発育にともないそれらの細胞の割合が減少するこ とを示している. 本研究に括いても同様の傾向が 示されたこと及び反応産物の局在 (Fig. 1) から, 今回同定した增殖期細胞のほとんどが活性化した 筋衛星細胞であると考えられた.ささらに, 総筋線 維数の増加と増殖期細胞数の減少とが対称的な推 移を示したこと(Fig. 2)から，筋線維数の増加と 筋衛星細胞との関連性も示唆された. また，この ことは筋衛星細胞が筋芽細胞であるとする Salleo $ら^{15)}$ の報告を支持するものである.

また, 筋の湿重量の推移も10週龄, 体重 $300 \mathrm{~g}$ 付近で変曲点が見られた．これは，総筋線維数の 増加との関連から考えると 10 週齢, 体重 $300 \mathrm{~g}$ 付 近までの筋重量の増加は筋線維の増殖と肥大の両 者によるものであり，それ以降の増加は主に筋線 維の肥大によるものであると推察された。さらに， 筋重量と体重の関係を検討したところ， $\mathrm{Y}=1.05$ $\mathrm{X}-0.02, \mathrm{r}=0.98$ の相関関係が示され, ラットの 発育発達過程に打いて生後 $2 \sim 20$ 週龄では筋重量 の増加は体重に依存しているものと考えられた。

また, 生後発育の指標として体重, 下腿長, さ らに腱の付着部位から下腿長の影響を最も受ける と考えられる EDL 長の推移を検討した結果, そ れぞれ10週齢，体重 $300 \mathrm{~g}$ 付近までは直線的に増 加し，それ以降の増加はゆるやかとなる傾向を示 し，下腿長と EDL 長の比率は10週齢，体重約300 $\mathrm{g}$ 以降で一定する傾向をした. すなわち，ウィス ター系雄性ラットに和けるこれらの成長の变曲点 が，10週齢，体重 $300 \mathrm{~g}$ 付近にあることが示され た、またこのような骨長と筋長の関係はおそらく 下腿の笳群全てに適応できるものと考えられ，前 述の M. Plantaris に打ける筋線維数之筇重量の 推移との関係から，10週㱓，体重約 $300 \mathrm{~g}$ までの 筋重量の増加は筋の長育と幅育の増加の両者によ るものであり, それ以降の増加は主に筋の幅育の 増加であると推察された.

一方, ラットに拈ける筋線維タイプの分化は,
生後約 4 週澮で完了する ${ }^{4,24)}$ とされている. しか し，本研究結果では，4 週齢の時点ではまだかな りの数の増殖期細胞が観察され, 笳線維数も 9,000 本以下であったことから，増殖期を経た未成熟な 筋線維の存在が考えられる.仮に, 動物の発育発 達過程に沶いて生体の諸器官が形態的・機能的に 急速に変化する時期を成長期，その速さが低下し 安定する時期を成熟期，さらに老化により形態 的・機能的低下がみられる時期を老龄期とするな らば ${ }^{28)}$ ，ラットの場合，4 週龄では一個の骨格筋 として成熟したとはいいきれず，成熟に至るのは 筋内の増殖期細胞が消長し, 筋線維数がほぼ一定 となる生後10週齡・体重約 $300 \mathrm{~g}$ 以降であること が示唆された。

以上の成績は, ウィスター系雄性ラットの発育 発達過程において, 骨格筋が成熟に至るのは, 体 重, 骨および筋の発育, さらに骨格筋内増殖期細 胞の消長と筋線維数がほぼ一定となる時期，すな わち生後10週齢・体重約 $300 \mathrm{~g}$ 以降であることを 示していた．これらのことは，筇肥大に関する研 究でウィスター系雄性ラットを用いる場合，常に 発育発達による影響を考慮すべきであり，さらに 骨格筋の発育発達に関する基礎的研究の必要性を 示唆するものであった.

\section{V. 要 約}

本研究ではウィスター系雄性ラットのM. Plan taris (PLA) における発育・発達にともなら総筋 線維数の变化及び筋肉内増殖期細胞（活性化した 筋衛星細胞と考えられる) の動向を, 週齡, 体重 の推移, 下腿長, 笳の湿重量及び筋の付着部位か ら下腿長の变化に最も影響を受けると考えられる M. Extensor Digitorum Longus (EDL) の筋長の 変化等の関連から免疫組織化学的に検討した.

(1) 発育発達にともないPLA の笳線維数は漸 次增加し 10 週齢, 体重 $300 \mathrm{~g}$ 付近で約 10,000 11,000本の間でほぼ安定する傾向を示した.

一方, PLA の増殖期細胞数の推移は筋線維数 とは対称的に10週龄, 体重 $300 \mathrm{~g}$ 付近まで漸次减 少し, それ以降ほとんど認められなかったことか ら, 発育・発達過程の筋線維数の増加にも筋衛星 
細胞が関与している可能性が示唆された.

（2）発有・発達にとるなら体重, 下腿長, EDL の筋長, PLA の筋重量の推移に拈いても, やは り10週齢, 体重 $300 \mathrm{~g}$ 付近で成長の変曲点がみら れ，それ以降の増加が緩やかとなる傾向を示した ことから，この 10 週龄, 体重 $300 \mathrm{~g}$ 付近が長育か ら幅育への一つの変曲点であると考えられた。

（3）発育・発達にともなら PLA の筋重量及び 体重の推移がほぼ等しい回㷌式によって示された ことから，今回用いた20週龄，体重 $400 \mathrm{~g}$ までの ラットでは体重と筋重量の増加率がほぼ等しいこ とが示された.

（4）発育・発達にともなら PLA の筋重量の推 移及び総筋線維数の増加を示した回帰式から，10 週齢, 体重 $300 \mathrm{~g}$ 付近までの筋重量の増加は, 筋 線維の增殖と肥大の両者によるものであり，それ 以降の増加は主に筋線維の肥大によるものである と考えられた。

（5）また，下腿長と EDL の笳長の比率が10週 龄, 体重約 $300 \mathrm{~g}$ 以降で一定する傾向を示した. このよらな骨長と筋長の関係は扰そらく下腿の筋 群全てに適応できるものと考えられ，PLAに拈け る筋線維数と筋重量の推移とを考号合わせると， 10 週龄，体重約 $300 \mathrm{~g}$ までの筋重量の増加は筋の 長育と幅育の両者によるものであり，それ以降の 増加は主に筋の幅有に依存するものであると推察 された。

以上の結果から，ウィスター系雄性ラットの骨 格筋の場合，一個筋が筋全体として成熟したと考 えられるのは10週龄, 体重約 $300 \mathrm{~g}$ 以降であった。 これらのことは筋の肥大や筋線維の増殖等の研究 を行ら場合, 発育発達の影響を除外するために, この点を考虑して行わなければならないことが考 えられた。

（受付 平成 4 年 5 月18日）

\section{References}

1) Allbrook, D. B., Han, M. F. and Hellmuth, A. E. (1971): Population of muscle satellite cells in relation to age and mitotic activity. Pathology, 3, 233-243.
2) Alway, S. E., Gonyea, W. J. and Davis, M. E. (1990): Muscle fiber formation and fiber hypertrophy during the onset of stretch-overload. Am. J. Physiol., 259, C 92-C 102.

3) Appell, H. J., Forsberg, S. and Hollmann, W. (1988) : Satellite cell activation in human skeletal muscle after training: Evidence for muscle fiber neoformation. Int. J. Sports Med., 9, 297-299.

4) Baldwin, K. M. (1984): Muscle development : neonatal to adult. Exercise Sports Sciences Reviews, 12, 1-9.

5) Chiakulas, J. J. and Pauly, J. E. (1965) : A study of postnatal growth skeletal muscle in rat. Anat. Rec., 152, 55-62.

6) deFazio, A., Leary, J. A., Hedley, D. W. and Tattersall, M. N. T.(1987) : Immunohistochemical detection of proliferating cells in vivo. J. Histochem. Cytochem., 35, 571-577.

7) Garner, R. P., Terracio, L., Borg, T. K. and Buggy, J. (1991) : Intra-cranical self stimulation motivates weight-lifting exercise in rat. J. Appl. Physiol., 71, 1627-1631.

8) Gonyea, J. W., Sale, D. G., Gonyea, F. B. and Mikesky, A. (1986): Exercise induced increases in muscle fiber number. Eur. J. Appl. Physiol., 55, 137-141.

9) Gratzner, H. G. (1982) : Monoclonal antibody to 5-bromo- and 5-iododeoxuridine : A new reagent for detection of DNA replication. Science, 218 , 474-475.

10) Kelly, A. M. (1978) : Satellite cell and myofiber growth in the rat soleus and extensor digitorum longus muscle. Develop. Biol., 65, 1-10.

11) Kevin, C. D. and Edward, S. (1987) : Exerciseinduced satellite cell activation in growing and mature skeletal muscle. J. Appl. Physiol., 63, 1816-1821.

12) Kevin, C. D. and Schultz, E. (1989): Hindlimb suspension suppresses muscle growth and satellite cell proliferation. J. Appl. Physiol., 67, 1827-1834.

13) Ontell, M. and Dunn, R. F. (1978): Neonatal muscle growth: A quantitative study. Am. J. Anat., 152, 539-556. 
14) Rayne, J. and Crawford, G. N. C. (1975) : Increase in fiber numbers of the rat pterygoid muscles during postnatal growth. J. Anat., 119, 347-357.

15) Salleo, A., Anastasi, G., La Spada, G., Falzea, G. and Denaro, M. G. (1980): New muscle fiber production during compensatory hypertrophy. Med. Sci. Sports Exerc., 12, 268-273.

16) Schltz, E. (1989) : Satellite cell behavior during skeletal muscle growth and regeneration. Med. Sci. Sports Exerc., 21, 181-186.

17) Snow, M. H. (1990) : Satellite cell response in rat soleus muscle undergoing hypertrophy due to surgical ablation of synergists. Anat. Rec., 227, 437-446.

18) Tamaki, T., Akatsuka, A., Itoh, J. and Nakano, S. (1989) : A newly modified isolation method of single muscle fibers-Especislly useful in histological and electron microscopic studies on branched fibers-. Tokai J. Exp. Clin. Med., 17, 211-218.

19) Tesch, P. A. (1988) : Skeletal muscle adaptations consequent to long-term heavy resistance exer- cise. Med. Sci. Sports Exerc., 20, S 132-S 134.

20) Timiras. s. p. (寺沢 塋・江上信雄監訳) (1972)： Developmental Physiology and ageing. (ティラミ ス生理学. 発育と老化のしくみ), 序説・第 I 編発 育の生理学. 丸善株式会社, 東京, 3-14.

21) Timo, H. and Hannu, K. (1992) : Activation of myogenic precursor cells after muscle injury. Med. Sci. Sports Exerc., 24, 197-205.

22) Tomanek, R. J. and Woo, Y. K. (1970) : Compen. satory hypertrophy of the plantaris muscle in relation to age. J. Geront., 25, 23-29.

23) Umnova, M. N. and Seene, T. P. (1991) : The effect of increased functional load on the activation of satellite cells in the skeletal muscle of adult rats. Int. J. Sports Med., 12, 501-504.

24) Vuokko, K.(1989) : Effects of ageing and physical training on rat skeletal muscle. Act. Physiol. Scand., 135 (Suppl. 557), 6-56.

25) Yarasheski, K. E., Lemon, P. W. and Gilloteaux, J. (1990) : Effects of heavy-resistance exercise training on muscle fiber composition in young rats. J. Appl. Physiol., 69, 434-437. 